\title{
HISTORY
}

\section{THE CULTURE OF HELUO IS THE MAIN CULTURE OF CHINESE CIVILIZATION}

\author{
Jin Lipeng, \\ PhD of department history of the Belarusian State University, Minsk, Belarus
}

DOI: https://doi.org/10.31435/rsglobal_sr/30062020/7142

\begin{abstract}
ARTICLE INFO
Received 23 April 2020

Accepted 12 June 2020

Published 30 June 2020

\section{KEYWORDS}

Heluo culture, Chinese civilization.

ABSTRACT

With the archaeological discoveries of the ancient Heluo Kingdom, Chinese archaeologists' research on Heluo civilization has become a hot topic in the current archaeological community. National leaders also attach importance to the study of Heluo civilization, which is the protection of Chinese cultural heritage and the study of China. The major support of the civilization process, this article analyzes the inheritance of the Heluo culture from the historical perspective for thousands of years, and provides some suggestions for archaeologists and historians to study Chinese civilization.
\end{abstract}

Citation: Jin Lipeng. (2020) The Culture of Heluo is the Main Culture of Chinese Civilization. Science Review. 5(32). doi: 10.31435/rsglobal_sr/30062020/7142

Copyright: (C) 2020 Jin Lipeng. This is an open-access article distributed under the terms of the Creative Commons Attribution License (CC BY). The use, distribution or reproduction in other forums is permitted, provided the original author(s) or licensor are credited and that the original publication in this journal is cited, in accordance with accepted academic practice. No use, distribution or reproduction is permitted which does not comply with these terms.

As the only civilization in the world lasting five thousand years without interruption, Chinese civilization has its unique cultural genes. The Chinese civilization is a multi-ethnic culture with Han nationality as the main body in the east of the world. Its outstanding features are "five thousand years" and "continuity ". More than five thousand years ago, different regions of China had formed different cultures, such as Hongshan culture in Inner Mongolia Autonomous Region and Liangzhu culture near Zhejiang Province. The so-called Heluo area mainly refers to the western and central Henan Province today, the eastern part of Shaanxi Province and the southern part of Shanxi Province. As a cultural concept," he Luo "has both regional significance and humanistic connotation. According to the historical situation and actual influence range of the Xia and Shang dynasties, Si Maqian's "river Luo" refers to the "Henan ", and "Hedong" areas centered on Luoyang, where the Yellow River and Luohe meet.

The development of Heluo culture, inherited from the Neolithic Yangshao culture, formed in the Xia, Shang and Wednesday dynasties, developed in the Han, Wei, Jin, Southern and Northern dynasties, flourished in the Sui, Tang and Northern Song dynasties, after the Song Dynasty began to transform or decline. As early as 700,000 years ago, here has Luanchuan people in this life. After entering the Neolithic Age, after several stages of Pei Li Gang culture, Yangshao culture and Henan Longshan culture, social productive forces have made more progress. Grinding stone tools, pottery has been constantly improved, casting technology began to appear. The Han tribes living in the Heluo region took the lead in getting rid of barbarism and ignorance, establishing an early country and stepping into the threshold of civilized society. The prehistoric culture in Heluo area occupies an important position in the origin of Chinese civilization and is an important core culture of the early Chinese civilization.

The site of Shuanghuai Tree, located in Gongyi City, Henan Province, was identified as a Duyi site in ancient times around 5300 years. This is more than 5300 years ago, located in the south bank of the Yellow River on the platform of the Yellow River, the Yiluo flow into the Yellow River, the middle and late Yangshao site in the central area of Heluo was proved to be a Duyi site in the ancient times. 
Because it is located in the central area of Heluo, it is named "Heluo ancient country". Shuanghuai tree site is located in the south bank of the Yellow River on the platform, Yiluo into the Yellow River in Gongyi City, Henan Province, Heluo Town. From the results of archaeological excavations, it is the only and the highest specification of the Yellow River Valley Duyi nature of the central settlement. Within the remaining 1.17 million square meters of the site, Three large-scale trenches, walls with the earliest structure of the urn city, large-scale central site with a closed layout, large-scale rammed earth base site, large-scale laminated rammed earth remains, three large-scale public cemeteries large-scale public cemeteries with strict planning, three rammed earth sacrificial platform relics, large tombs surrounding the rammed earth sacrificial platform around the center, nine astronomical relics of the Big Dipper simulated with nine pottery pots fused with large buildings inhabited by important figures, the earliest domestic silkworm tooth carving works with important connections to the origin of silk, the ritual relics of more than 20 human sacrifices or animal sacrifices, and the pottery workshop areas, water storage areas, road systems, etc. not specify the high spec here. The most famous unearthed object at the site of the Shuaghuai tree should be a silkworm carved with wild boar tusks. This one is 6.4 centimeters long, less than a centimeter wide, it's $0.1 \mathrm{~cm}$ thick, is a silk is spitting image of the silkworm. To be more certain, this should be the first place in the world to produce silk at that time. A series of important archaeological discoveries, "Central Plains Civilization Development Model ", represented by the site of Shuanghuai Tree, Center and cultural inclusion, pay attention to people's livelihood, farm mulberry, not too much of the social wealth created to the gods, but more into social reproduction. The subject of this model is inherited and developed by the mainstream political society in future generations, become the most representative and leading mainstream development mode and thought in the historical process of Chinese civilization. The view of the universe in heaven and earth, the ceremonial thinking of rule by destiny, Large, high - grade buildings, Rigorous and orderly settlement layout, The core of the earliest urban agglomeration in China's geographical center, The connotation of the double Shuanghuai tree site, especially the social development model and carrying ideology, In the ancient times, The Big Dipper and many other phenomena that highlight ritual and civilization, By the later Xia, Shang and Zhou dynasties civilization inherited and carried forward, More than five thousand years of Chinese civilization is based on this root and continuous. The double Shuanghuai tree site is the early stage of the formation of Chinese civilization in Yangshao culture in the Yellow River Basin. The highest - sized central settlement of the city, Therefore, experts and scholars called the "embryo of early Chinese civilization".

In the 1950s, The Erligang site of the early Shang Dynasty was discovered in Zhengzhou, Henan Province, Zhengzhou Mall plane is rectangular, The perimeter of the wall is 6960 meters, There are 11 gaps, Some of them might be the gates, There's a palace in the northeast, Found a number of palace sites, The heart of the stone masonry artificial water storage facilities. There are also small houses and wells in the city. Outside the city there are residential areas, cemeteries, cast copper sites and pottery bone workshop sites. Small tombs are mainly pottery; Medium - sized tombs with bronze objects, and There are martyrs in a tomb. A section of the outer wall was also found outside the south city. In addition, found two copper hoardings, considered the ritual ware of Shang Wang Xuan. East and northeast of the central part of Zhengzhou Mall, about 1/6 of Zhengzhou Mall, Remains of various uneven rammed earth foundation, the bases are not well organized, but closer to the northeast corner, the southwest is sparse, more than 20 foundation sites of Shang Dynasty rammed earth were discovered in the northeast corner. Large area of over 2,000 square meters, Small only more than 100 square meters. Some of the rammed earth base is also preserved in the column hole, column base groove and column, show that this is the palace district of the Shang Dynasty. South central, found a Shang Dynasty rammed earth building base site, it should be where the slave owners live. In the city, we found some smaller buildings, Could be a civilian settlement. Outside the city, found a number of according to a certain layout of the establishment of handicraft workshop sites. Outside the north city wall is the site of the copper-casting workshop, a bone-making workshop was found in the north of the site. Outside the south wall found a copper-casting workshop site, outside the west wall found a pottery workshop site.

The site of Yanshi Mall in Luoyang, covering 1-4 meters below the ground. Found in the spring of 1983 in conjunction with infrastructure projects, The Institute of Archaeology of the Chinese Academy of Social Sciences has carried out many excavations, The site of Yanshi Mall in Luoyang, A little rectangular, More than 1700 meters north and south, East - west 1215 meters 740 meters, 
Including big city, small city, palace city triple wall. City site found in the city gates, roads, palaces, residential sites and other relics, and unearthed a large number of stone tools, pottery, bronze, jade and other relics. Yanshi business city site is divided into three parts: Palace, small city, big city, A little rectangular, more than 1700 meters north and south, 1215 meters in the north, about 1120 meters wide in the middle, 740 meters south, the area is about 1.9 million square meters. The walls are rammed earth, the south wall has been destroyed by the Luo River. The west wall is 1710 meters long, The North wall is 1240 meters long, East wall is now 1640 meters long. Seven gates, One to the North, Three seats each. A number of crisscrossed main roads and block-built square drains were found in the city. Of which five are on the road, Six North - South roads, $6 \sim 10$ meters wide, some of these roads correspond to the orientation of the gates. There are three small towns in the south half of the city, Palace is in the middle, A square, A large palace base in groups; The other two towns are in the northeast and southwest of Palace, All rectangular, With rows of buildings, Could be a bunker, a granary or a garrison castle. The site has large palace buildings and military defenses, the city is well drained, there are trenches, drains, canals, the streets, the king's cities, treasuries, barracks and gates were arranged in an orderly manner. Experts noted that It was the earliest, largest and most wellpreserved capital in the early Shang Dynasty.

Erlitou site is located in Yanshi City in the east of Luoyang Basin. The most abundant cultural remains on the site are about 3800 3500 years ago. The site south of ancient, north, back. Erlitou site has important reference value to the origin of research, the rise of the country, the origin of the city, the construction of Wang du, the customization of the palace and so on. The central road network, square rules of the Palace and with the central axis of the planning of the building base group, indicating that Erlitou site is a careful planning, layout of a large. It is the earliest Duyi site that can be confirmed so far, which has clear plan and the construction regulation of ancient Chinese capital city. The discovery and excavation of Erlitou site is of great significance and has great influence at home and abroad. China is one of the few ancient civilizations on earth with independent origin, and the only country in the history of the four ancient civilizations.

The Heluo culture is an important symbol of the five thousand years of Chinese civilization history, and it is also the source of the five thousand years of Chinese national history. In ancient China, Heluo culture once showed great cultural soft power: internally, it highlighted strong cohesion and centripetal force, maintained the reunification of the motherland and national unity, and guaranteed China's long-term prosperity; externally, it was widely recognized and respected by other cultures, showing a good international image of China. In the study of the origin and formation of ancient Chinese civilization, at the same time, it is found that such as Hongshan culture located in the present Inner Mongolia Autonomous region, Liangzhu culture in Zhejiang Province, Sanxingdui culture in Sichuan Province, etc. Some scholars believe that the diversity of ancient Chinese civilization is very important, which leads to the weakening of the core significance of the civilization in the Heluo region in history. However, in practice, Heluo culture occupies a dominant position in the long history of Chinese civilization, and has assimilation and important influence on archaeological culture in other places. The ancient civilization has been formed in Heluo ancient country since 5300 years ago, which is already the archaeological culture of the early countries. As the root of Chinese culture, Heluo culture has given full play to the integration of its culture in history and promoted the formation of the pluralistic and integrated pattern of the Chinese nation. He Luo culture is a kind of root culture, no matter where the Chinese go, they all have deep feelings for their ancestral home, and have been the strong cohesion and centripetal force of Heluo culture are firmly united. Heluo culture contains the spirit of "harmony "," harmony "," inclusive" and other spiritual connotations and other nationalities seeking common ground while reserving differences, open and inclusive ideological essence of the same work, the same line, is also the core values of the Chinese nation for thousands of years.

\section{Conclusions.}

In summary, I believe that Heluo culture occupies an important position in the five thousand years of civilization development in China. The tolerance and uniqueness of Heluo culture is also an important factor in the continuous development of Chinese civilization. The status of Luo culture in Chinese civilization is helpful to the development of China's cultural undertakings. 


\section{REFERENCES}

1. Archaeological Research and Marxist Guidance - Visiting Liu Qingzhu, Member of the Academic Department of the Chinese Academy of Social Sciences and former Director of the Institute of Archaeology 1. Qin Yicheng. Marxist studies. 2014(09)

2. Miaodigou Age and Early China 2. Han Jianye. Archaeology. 2012(03)

3. Mausoleum Site of Liao Dynasty in Balin Zuo Banner, Inner Mongolia 3. Dong Xinlin, Tara, Kang Lijun, Xiao Huaiyan. Archaeology. 2009(07)

4. China's Prehistoric Foundation - On the Historical Trend centered on the Central Plains 4. Zhao Hui. Cultural relics. 2006(08)

5. A New Understanding of Civilization and State Origin5[N]. Yi Jianping. China Social Sciences Journal. 2011(005)

6. Some Problems in Archaeology of Ancient Chinese Capital City6[J]. Liu Qingzhu. Archaeology .2000(07)

7. Thoughts on the Archaeology of Ancient Chinese Palace Ruins7[J]. Liu Qingzhu. Archaeology and Cultural Relics. 1999(06)

8. The earliest China [M]. Science Press, Xu Hong, 2009

9. Formation and Development of Chinese Civilization [M]. Elephant Publishing House, Henan Institute of Cultural Relics and Archaeology, 2003

10. Archaeology Collection [M]. China Social Sciences Press, by Archaeological Editor, 1987

11. Origin of Chinese Civilization [M]. Cultural Relics Publishing House, by Xia, 1985

12. Archaeological Discovery and Research in New China [M]. Institute of Archaeology, Chinese Academy of Social Sciences, 1984 